\title{
1975 Archaeological Investigations at Old Ursuline Academy San Antonio, Texas
}

Paul R. Katz

Follow this and additional works at: https://scholarworks.sfasu.edu/ita

Part of the American Material Culture Commons, Archaeological Anthropology Commons, Environmental Studies Commons, Other American Studies Commons, Other Arts and Humanities Commons, Other History of Art, Architecture, and Archaeology Commons, and the United States History Commons

Tell us how this article helped you.

This Article is brought to you for free and open access by the Center for Regional Heritage Research at SFA ScholarWorks. It has been accepted for inclusion in Index of Texas Archaeology: Open Access Gray Literature from the Lone Star State by an authorized editor of SFA ScholarWorks. For more information, please contact cdsscholarworks@sfasu.edu. 
1975 Archaeological Investigations at Old Ursuline Academy San Antonio, Texas

Creative Commons License

(C) $(1) \Theta$

This work is licensed under a Creative Commons Attribution-NonCommercial 4.0 International License 


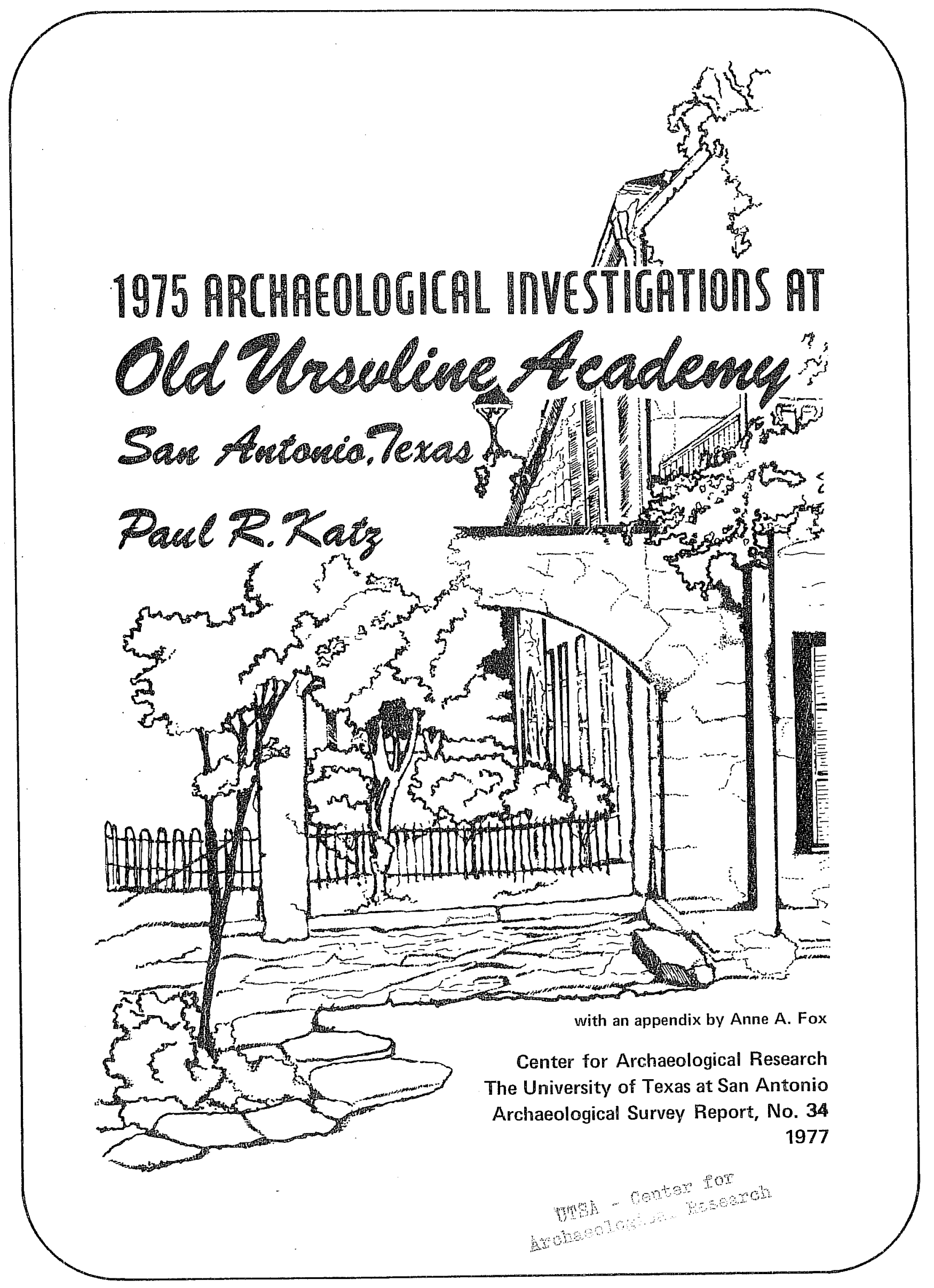


1975 ARCHAEOLOGICAL INVESTIGATIONS AT OLD URSULINE

ACADEMY, SAN ANTONIO, TEXAS

Paul R. Katz

With an appendix by

Anne A. Fox

Center for Archaeological Research The University of Texas at San Antonio Archaeological Survey Report, No. 34

1977 
TABLE OF CONTENTS

LIST OF FIGURES

Page

LIST OF TABLES

ii

ii

INTRODUCTION

1

FIELDWORK

1

Design

4

Excavation

4

Construction

6

Interviews

10

Chape 1

10

SPECIMEN ANALYSIS

11

CONCLUSIONS

15

REFERENCES CITED

25

ACKNOWLEDGMENTS

26

APPENDIX: Ceramic Analysis

28

Descriptions

29

Observations

31

References Cited

31 


\section{LIST OF FIGURES}

Figure Page

1. Outline of 01d Ursuline Academy Building Complex in 2 Downtown San Antonio.

2. Dormitory and Adjacent Buildings, Showing Relation- 3 ship of Excavation Units.

3. Dormitory Floor Plans. 5

4. Generalized Stratigraphic Profile of the Courtyard 7 South of the Dormitory.

5. Dormitory Excavation Units. $\quad 8$

6. Dormitory Excavation Units. 9

7. Selected Specimens Recovered from the Dormitory 20 Excavation Units.

\section{LIST OF TABLES}

Table Page

1. Specimen Function Classification (after Schneider 1970). 12

2. Classification of Recovered Specimens According to 14 Function Category Code.

3. Classification of Specimens Recovered from Excavation 16 Unit $B$.

4. Classification of Specimens Recovered from Excavation Unit C.

5. Classification of Specimens Recovered from Excavation Unit D.

6. Classification of Specimens Recovered from Excavation Unit E.

7. Comparison of 1974 and 1975 Excavation Data. 


\section{INTRODUCTION}

Archaeological investigations were conducted at 01d Ursuline Academy (41 BX 235), presently the Southwest Craft Center, during the month of October, 1975. This work was necessitated by planned renovations to the dormitory building, one of the complex of nineteenth century buildings listed on the National Register of Historic Places (Figs. 1,2).

The nature of the renovation would consist of excavating below the present floor of the dormitory basement so that air conditioning ducts and blower units might be installed; transformation of this basement from a storage place into a series of functional rooms and galleries; construction of a new entryway into the basement from the south (Figs. 2, 3); and the construction of a French drain along the south side of the dormitory to prevent flooding of the basement area (Fig. 2).

Archaeological excavation units were located in those areas to be most severely disturbed by construction activities: two units in the dormitory basement and three units in the courtyard close to the south wall of the dormitory (Fig. 2). Preliminary analysis of the excavation data showed significant parallels with the 1974 Texas Historical Commission investigations (Clark 1974), permitting a clearance letter to be written almost immediately. Subsequent detailed analyses led to the postulation of a number of activity patterns and foci, with the conclusion that the dormitory courtyard portion of the site can provide a degree of scientific and historic data far in excess of the space that it occupies relative to the rest of the site.

Architects for the "Renovation of Dormitory Project" were the firm of Ford, Powell and Carson of San Antonio, and Mr. Roland A. Baylor was the general contractor. Dr. Thomas R. Hester, Director of The University of Texas at San Antonio Center for Archaeological Research, directed the archaeological portion of the project, with Dr. Paul R. Katz supervising the fieldwork and subsequent analysis of collected data and material.

Funding for the archaeological investigations was provided by the Southwest Craft Center and the Texas Historical Comission. Mrs. Donald Saunders, Chairman of the Board of the Southwest Craft Center, and Mr. Dan Scurlock, Research Archeologist with the Texas Historical Commission, represented, respectively, those two organizations while the archaeological investigations were being conducted.

\section{FIELDWORK}

The field portion of the archaeological investigations can be considered as a series of four phases, with a fifth phase brought about by subsequent construction in the chapel building during December, 1976 (Fig.2). First a testing plan was formulated, based on the nature and extent of proposed disturbances to the exterior ground surface and interior basement floor. The actual excavations were then conducted, prior to the initiation of any construction activity. Several observations were made during the period of construction, with special attention being paid to the deep trench dug for the drain. Interviews with current and former residents of the dormitory and other buildings constituted another, and quite valuable, field activity; while actually a 


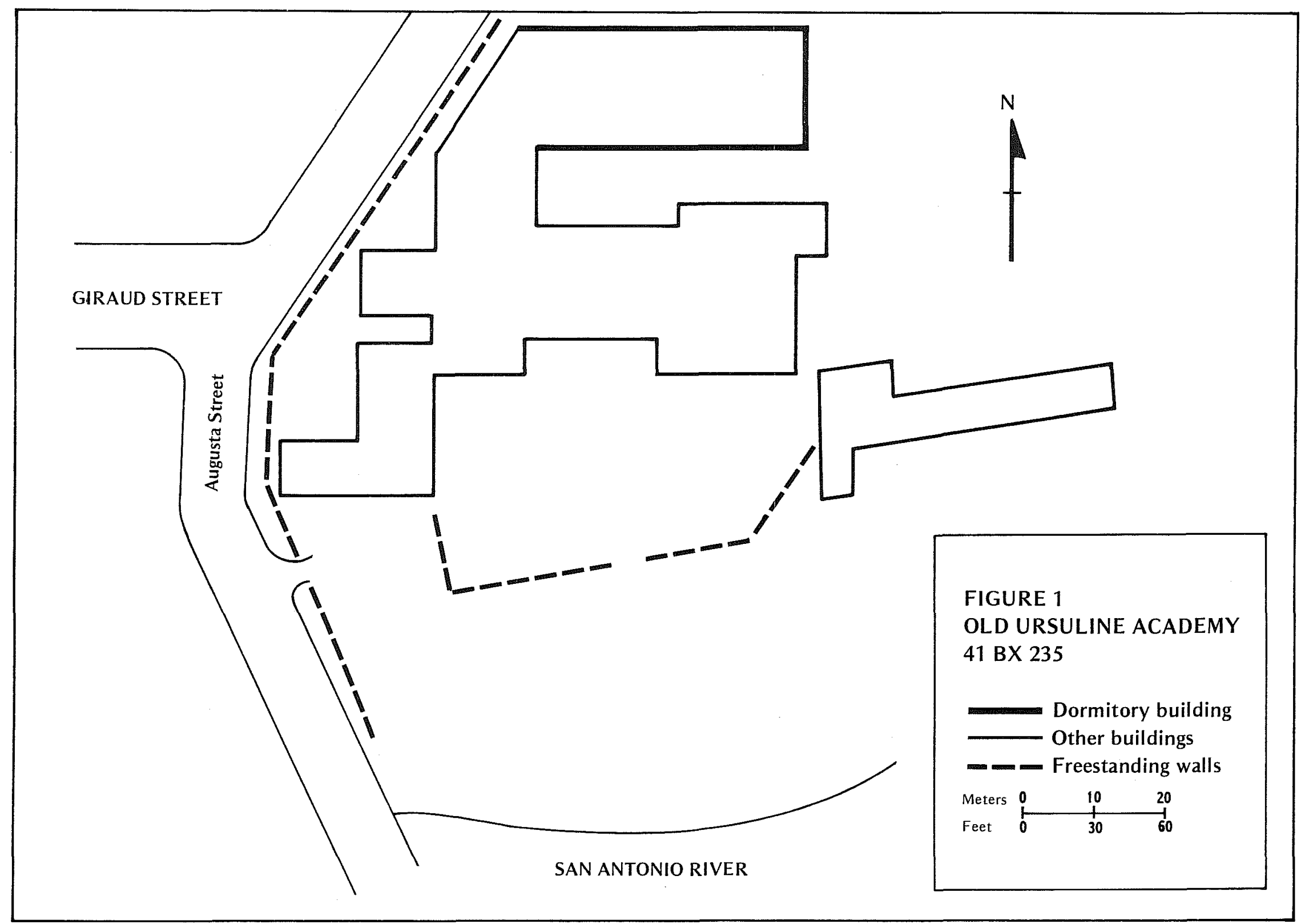

N

Figure 1. Outline of old Ursuline Academy Building Complex in Downtown San Antonio. Dormitory building is the northernmost, indicated by bolder outlining. 


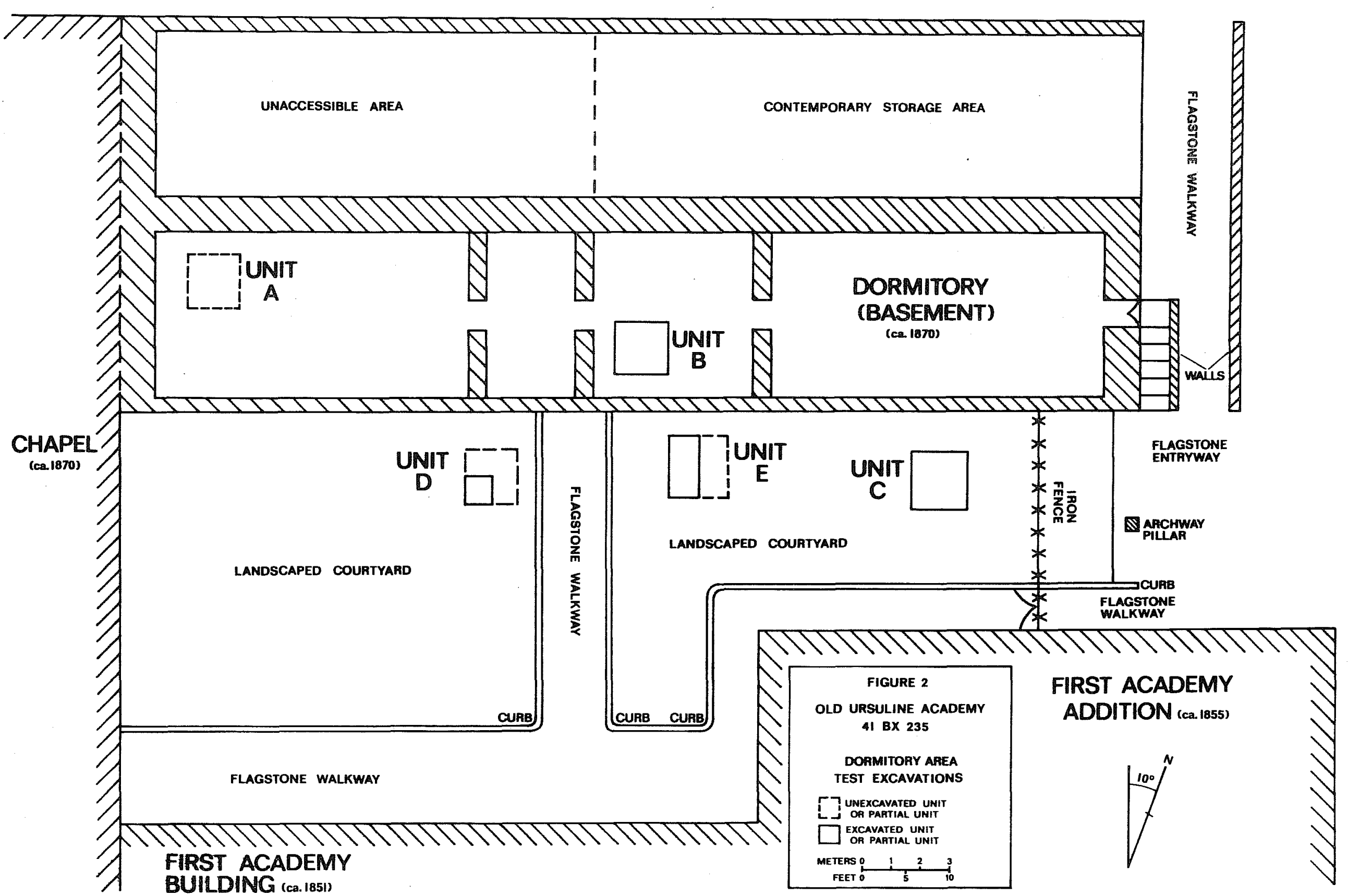

Figure 2. Dormitory and Adjacent Buildings, Showing Relationship of Excavation Units. Solid 
continuing process, this type of investigation can be considered a separate phase of the fieldwork. Finally, excavations beneath the chapel floor, also for the purpose of installing air conditioning equipment, resulted in additional visits to the site for the purpose of recording on film and paper the nature and extent of these subsurface disturbances.

Design

The excavation design devised to test for archaeological evidence in the dormitory area was a direct reflection of the proposed construction activity. Wherever construction activity was to be concentrated, some degree of archaeological excavation was also located. Figure 2 shows the excavation units as they were initially laid out, in relation to the exterior and interior of the dormitory building.

Units $A$ and $B$ were situated in the basement of the dormitory, close to the east-west centerline along which the ducts were to be laid. Units $C, D$ and E were laid out parallel to the exterior south wall of the dormitory, within the area which would be excavated during construction of the drain.

Each unit was initially laid out as a square two meters (6.6 feet) on a side. The sides were oriented parallel and perpendicular to the south dormitory wal1, which turned out to be 10 degrees off an east-west orientation. Excavation was to proceed by arbitrary 10-centimeter levels at first, then be modified to natural or cultural stratigraphic levels once information was obtained on the stratification below ground surface.

\section{Excavation}

Unit A (Fig. 5a) was located on the north side of the dormitory basement centerline, in the northwest corner of the westernmost room (Figs. 2, 3). It was never excavated, due to sufficient information having been recovered from Unit $B$.

Unit $B$ was located on the south side of the dormitory basement centerline, in the southwest corner of the east-central room (Figs. 2, 3). A11 four onemeter quadrants were excavated to a depth of six centimeters ( 2.4 inches), the matrix consisting primarily of accumulated dust. A very compacted, reddish clay was encountered at six centimeters and excavated to a depth of 30 centimeters (one foot) in the southwest quadrant. No cultural material was recovered from within the clay, al1 materials occurring within the dust zone (Table 3). The nature of the recovered material will be considered in the following section. The total excavated volume was 0.48 cubic meters.

Unit C (Fig. 6a, b) was the easternmost of the three areas of the dormitory building (Figs. 2, 3). The entire two-meter square was excavated to a depth of 10 centimeters, with the southwest quadrant subsequentiy excavated to 30 centimeters below ground surface. All soil was screened through one-quarterinch mesh hardware cloth. The upper portion showed evidence of disturbance and mixing, and most of the artifacts were recovered from the first 10 centimeters. Toward 20 centimeters the soil became sandier and more homogeneous, 

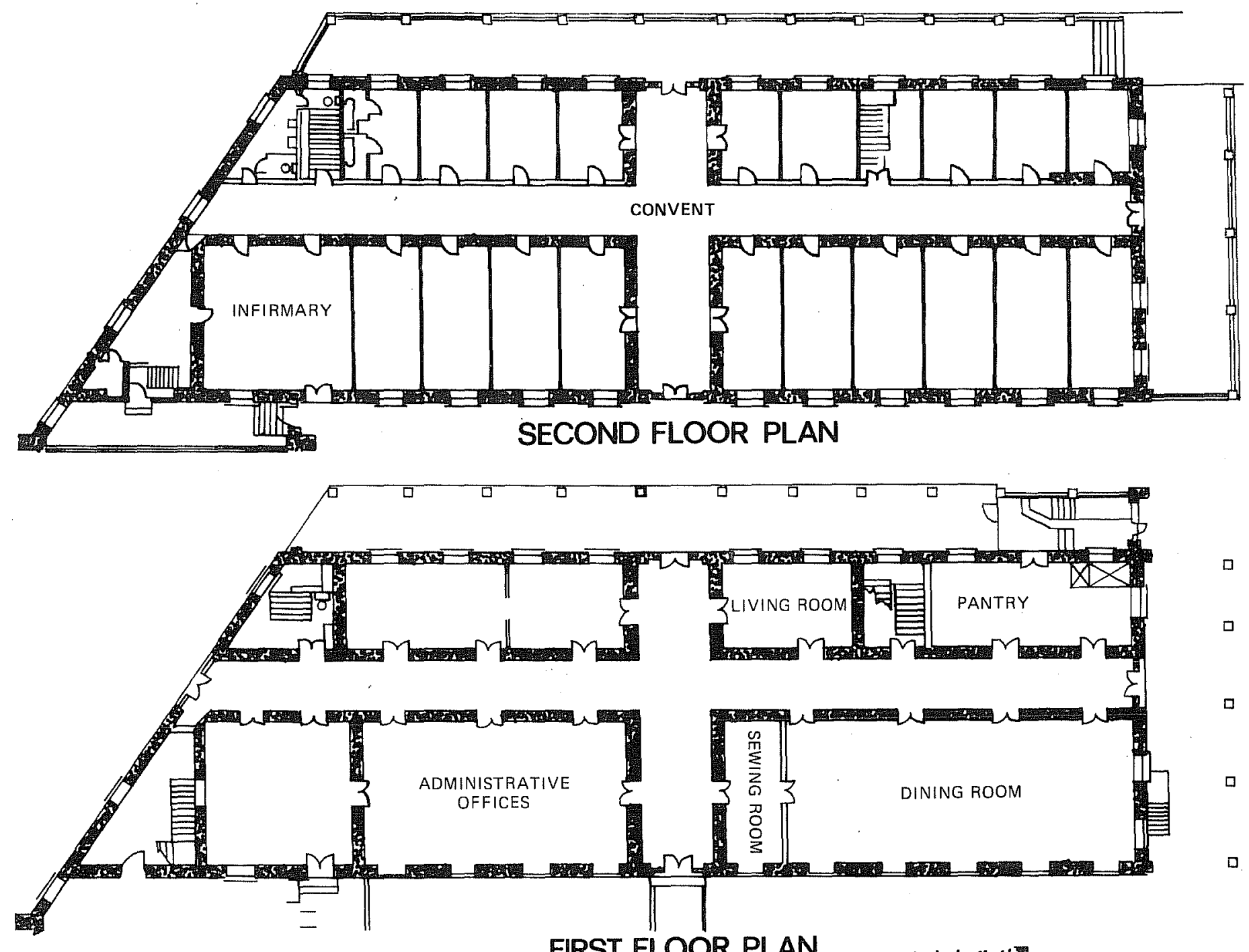

FIRST FLOOR PLAN
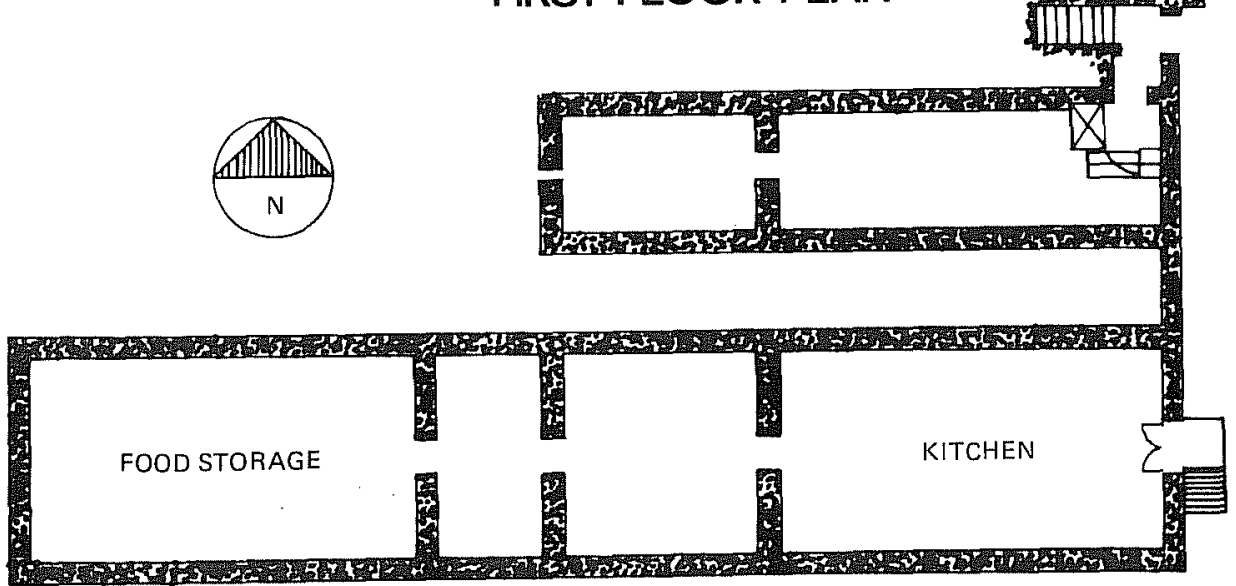

FIGURE 3

CELLAR PLAN

OLD URSULINE ACADEMY

DORMITORY FLOOR PLANS

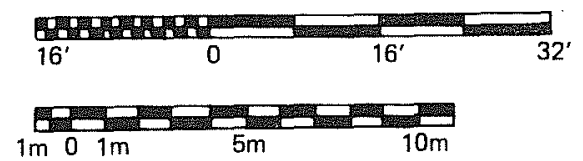

Figure 3. Dormitory Floor Plans. Room designations are the results of an interview with Sr. Genevieve Babin; plans after Historic American Building Survey No. TEX-3170 (1968). 
caliche nodules became more frequent, and the artifact yield dropped off significantly (Table 4). The nature of the recovered material will be considered in the following section. The total excavated volume was 0.60 cubic meters.

Unit $D$, the westernmost of the three exterior squares, was located on the western side of the dormitory's south entryway (Figs. 2, 5b). Unit D served as the stratigraphic control square, in that only one quadrant was excavated; this was taken much deeper than other units, however, to provide a profile of the various soil zones. It was also excavated by natural stratigraphic layers, to a depth of 80 centimeters below ground surface. With small variations ignored for the present, there seem to be two primary soil zones: a disturbed, brownish-gray soil which changes to a more compact tan clay by 50 centimeters below ground surface. Caliche nodules increase in frequency in the lower, tan clay zone, accompanied by an almost complete cessation of historical artifacts (Table 5). A one-inch diameter probe was sunk into the 80-centimeter deep urit floor, to an additional depth of 130 centimeters. This showed an increasingly lighter and more compacted clay subsoil, changing from light gray to the same reddish clay characterizing the basement floor. Figure 4 shows a generalized stratigraphic profile, based in part on the data derived from the Unit D excavation. The nature of the recovered material will be considered in the following section. This unit had the largest total excavated volume, with 0.80 cubic meters.

Unit $E$ was established as an intermediate exterior square in almost every respect. Its location on the east side of the south entryway placed it between Units $C$ and $D$ (Figs. 2, 5b). Two quadrants were excavated, in the western half of the square; both were taken down 20 centimeters, followed by only the southwest quadrant to a final depth of 50 centimeters below ground surface: All soil removed was screened through one-quarter-inch mesh hardware cloth. The total excavated volume of 0.70 cubic meters was again intermediate between Units $C$ and $D$. Although there were no stratigraphic differences between Units $E$ and $C$ from 0 to 30 centimeters and between Units $E$ and $D$ from 30 to 50 centimeters, quantitative differences in artifact yields are apparent (Tables 4, 5, 6). The nature of the recovered material will be considered in the following section; and the possible significance of these quantitative differences will be discussed in the concluding section.

\section{Construction}

Mlmost immediately following completion of the archaeological activity, construction began on the dormitory project. Trenches were cut into the basement floor for the air conditioning ducts, and a major trench was excavated along most of the south wall from the wall itself outward into the courtyard.

Periodic visits were made to observe this activity. Additional artifactual material was collected from these trenches, primarily to augment those artifact classes which were poorly represented by the archaeologically obtained excavations. The value of these latest artifacts was necessarily limited, however, due to the absence of exact provenience data and of their association with other artifacts in an undisturbed stratigraphic situation. 


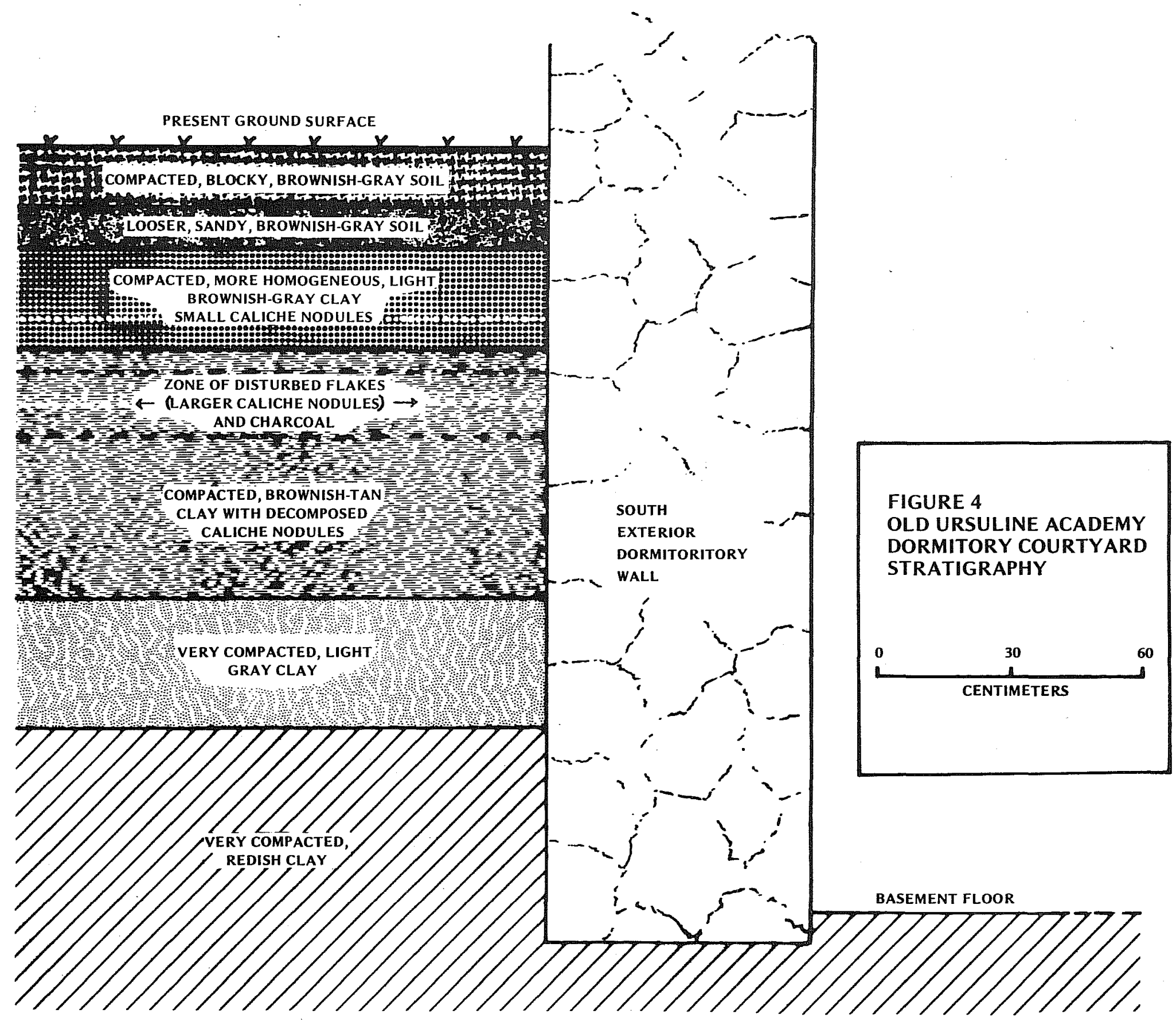

Figure 4. Generalized Stratigraphic Profile of the Courtyard South of the Dormitory. Sources include both archaeological and construction excavations. 


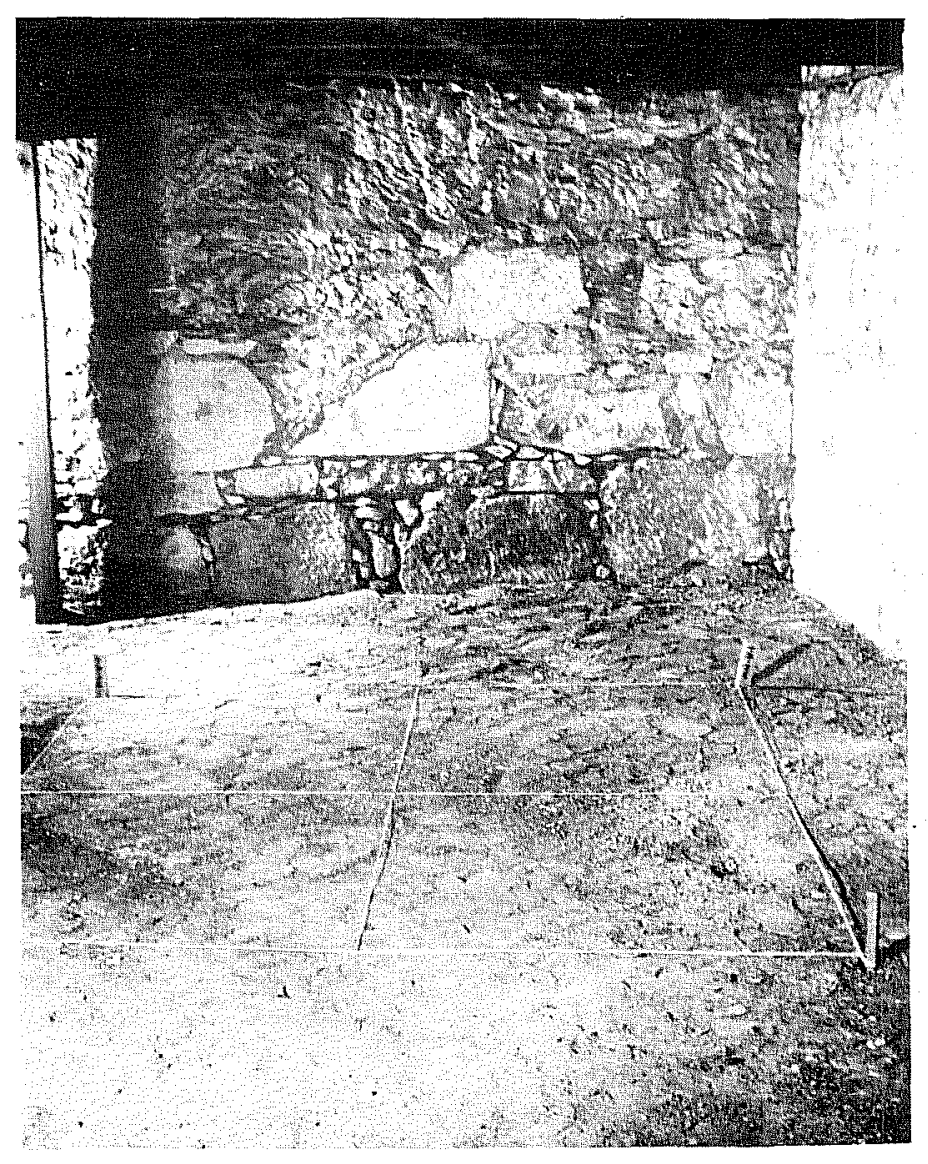

a

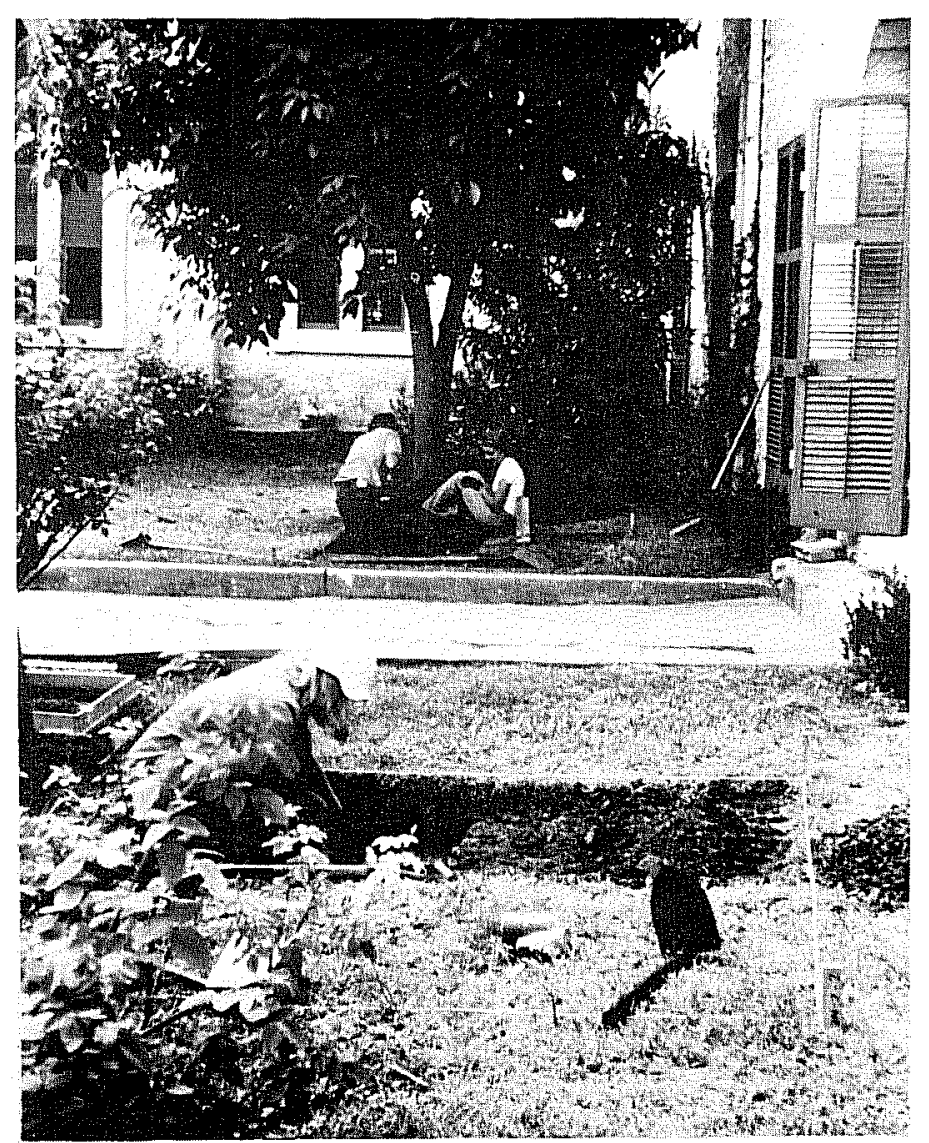

b

Figure 5. Dormitory Excavation Units. a, Unit A, located in the westernmost basement room, looking west (see Fig. 2); b, Units E (foreground) and D (background), looking west (see Fig. 2 ). 


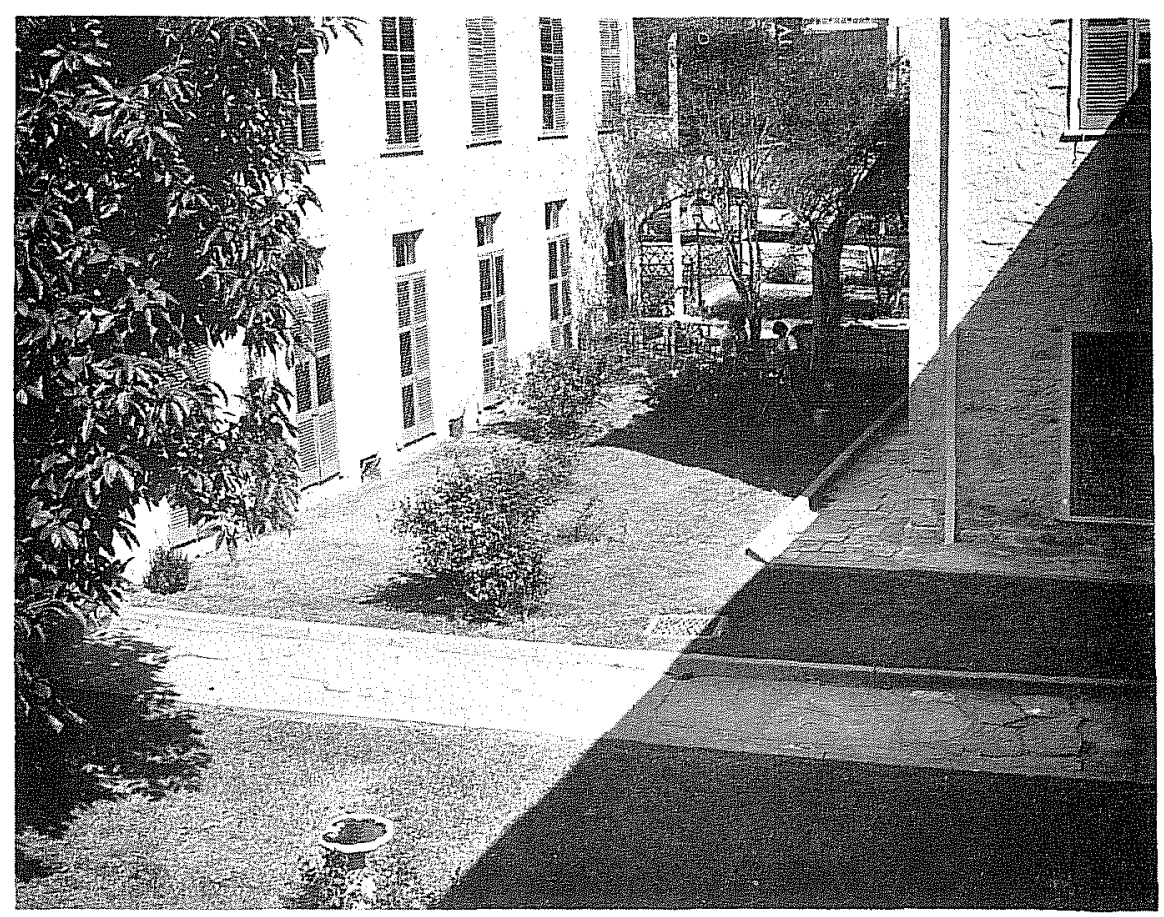

a

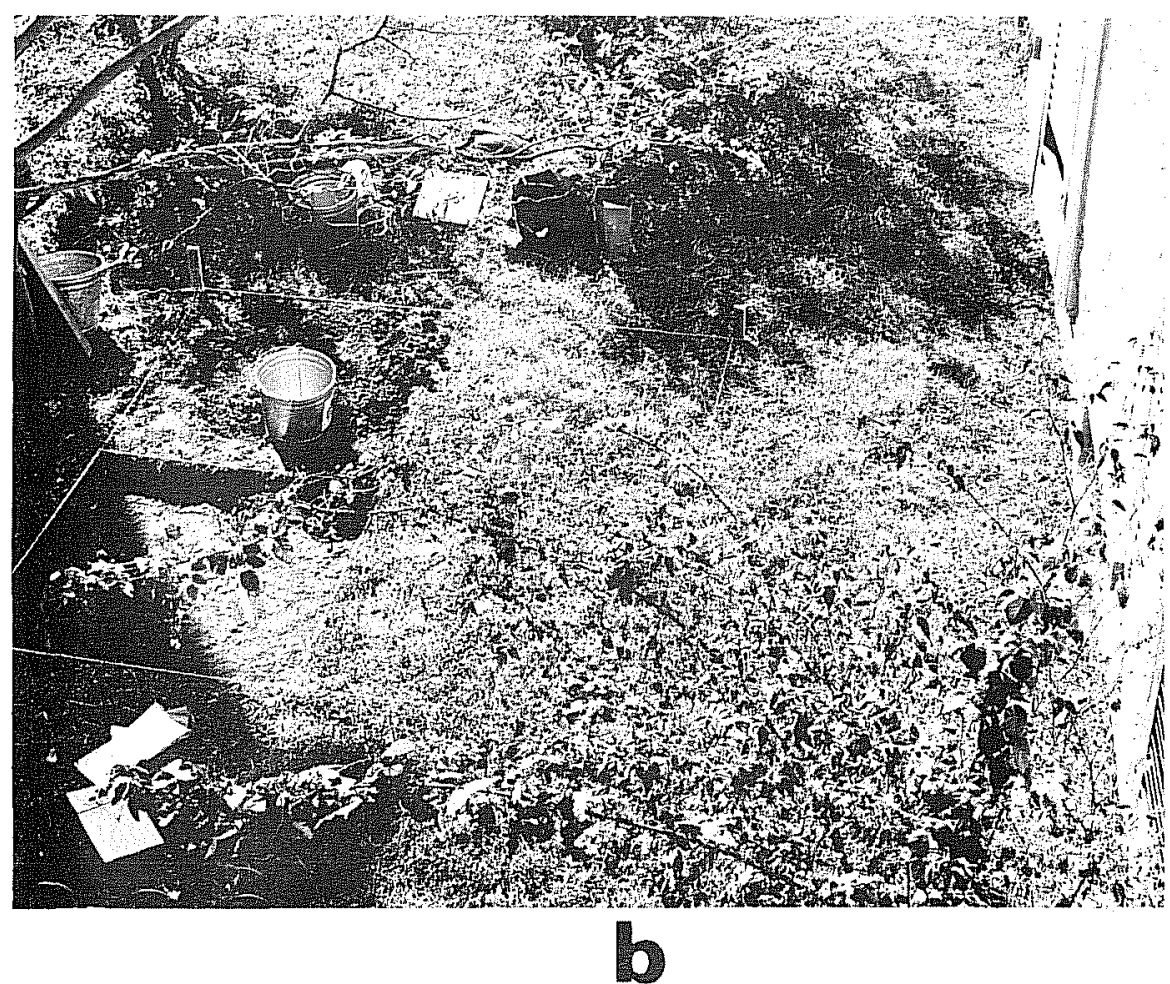

Figure 6. Dormitory Excavation units. a, courtyard on south side of dormitory building, with Unit $C$ in background, looking northeast (see Fig. 2); b, Unit $c$, looking southwest (see Fig. 2). 
Most valuable during the construction phase was the opportunity to observe a great deal of stratigraphy. The south dormitory wall had been exposed to its base, approximately 180 centimeters below ground surface. By comparing profile drawings of the south wall, the wall of the French drain trench, and the walls of excavated archaeological units (especially Unit D), a generalized drawing of the courtyard stratigraphy could be compiled (Figure 4).

In general, the entire stratification exhibits evidence of disturbance; the causes, however, seem to be of two kinds. The upper 50 centimeters (20 inches) appears to represent redeposited soil or landfil1, whereas the lower zones seem to reflect periodic alluvial deposition attributed to flooding of the San Antonio River immediately south of the site (Fig. 1).

The artifact collection reflects the natural stratigraphy, in that the uppermost 50 centimeters reflect a mixed inventory of prehistoric and historic material. Virtually no historic artifacts were recovered below 50 centimeters, but the chipped stone flakes were found in a variety of orientations suggesting movement from their original place of deposition. The preceding statement applies only to the courtyard area, however; in the basement, historic artifacts were recovered from inmediately above the subsoil, and any evidence of prehistoric occupation would have been removed during the building's construction.

\section{Interviews}

A number of interviews were conducted with present Southwest Craft Center administrators and staff. Information on room and grounds usage, pedestrian traffic flow, landscaping activities, and recent renovations al1 provided data useful for the interpretation of the uppermost stratigraphy and artifacts distribution.

Valuable time depth and a fascinating glimpse into the daily activities of 01d Ursuline Academy was provided by Sr. Genevieve Babin. Sr. Genevieve Tived at the Academy from 1915 to 1961 , at which time the present Academy and convent on Vance Jackson Road were opened. Information was obtained as to the function of some of the dormitory rooms (Fig. 3), in which 15-18 teachers and administrators usually lived. The building across the courtyard housed students and classrooms, al though al1 classroom activity was moved to a threestory classroom building constructed northeast of the dormitory in 1912. The courtyard was always much as it is at present, having a few trees, bushes and lawn. Artifacts lost or discarded in the courtyard area would be expected to reflect the scholastic, recreational, religious, and domestic activities of the students and sisters living on both sides of this area.

\section{Chapel}

In December of last year, construction activity took place in the chape building, located southwest of the dormitory and attached to the latter's western end (Figs. 1,2). The installation of a sub-floor air conditioning system prior to interior renovation resulied in a situation similar to that which characterized the dormitory a year before. It provided an opportunity to observe additional stratigraphy; and an historic drain was uncovered which had been the subject of some speculation during the 1974 archaeological investigations conducted by the Texas Historical Commission (Clark 1974). 
Sufficient portions of the stone-lined and stone-capped drain were exposed beneath the chapel floor to establish conclusively that it extends the entire north-south length of the chapel (Clark 1974: Fig. 3). Unfortunately, however, not enough of the northern portion was exposed to determine whether it turned northeast toward the dormitory or continued due north under the north wall of the chapel. As such, it still cannot be stated whether this drain was connected to a cistern below the northwest portion of the dormitory (Figs. 2, 3), as suggested by Clark (1974:36).

\section{SPECIMEN ANALYSIS}

A11 material recovered in the field, through excavation or from the surface, was removed to the laboratory for analysis. There each specimen passed through a series of specific procedures, which included: washing or cleaning; cataloging; identification, description and classification; and interpretation. The last stage serves to relate specimens in space and time, determine the function of these groups of related specimens, interpret why specimens were found where they were, and attempt to draw conclusions aimed at reconstructing the human behavior patterns or natural processes responsible.

The analyst is permitted some latitude in how the collection of specimens is subdivided and classified, although the ultimate classificatory scheme must be oriented toward the directions the interpretations are to take. For instance, a classification according to raw materials employed would not be appropriate for interpretations oriented toward reconstructing activity areas, where specimen functions need to be known. Not all specimens recovered in the field are artifacts. A competent field archaeologist wi7l take pains to collect representative samples of soils, vertebrate and invertebrate fauna, flora, and local stone varieties; al1 these must also be included in the analys is for comparison with culturally modified and utilized specimens.

The classification system selected for the current analysis is based primarily on an object's function, with some modification for non-artifactual specimens. First developed at the Lowie Museum of Anthropology, University of California at Berkeley, it was subsequent7y incorporated into A Guide to Inventorying Ethnological Collections (Schneider 1970), the latter compiled between 1965 and 1970 at the Stoval Museum, University of OkTahoma, and the Museum of Anthropology, University of Missouri at Columbia. Table 1 reproduces the classificatory framework, which consists of major functional classes and associated functional categories. Each category is assigned a unique code number, the first digit of which reflects its general class. The system has been slightly modified to introduce some time depth and to enable the inclusion of natural (vs. artifactual) specimens, by means of a series of suffixes attached to the code number as appropriate.

Tabie 2 provides a listing of the specimens recovered from the field, according to their functional categories. Unless otherwise indicated by a suffix on the category code number, a specimen is considered to reflect human utilization or manufacture and to date either to the historic or present periods. No distinction is here attempted between them; it is more to the point to contrast 
TABLE 1

Specimen Function Classification

(after Schneider 1970)

100 UTENSILS AND IMPLEMENTS

101 Unclassified

102 Hunting

103 Fishing

104 Gathering

105 Agriculture and Animal Husbandry

106 Household

107 Manufacturing

108 Fighting

109 Toilet Articles; Personal Hygiene; Personal Belongings

117 Child Care, Training, and Education

112 General Utility

200 DRESS AND ADORNMENT

201 Unclassified

202 Daily Garb

203 Personal Adornments and Ritual Regalia; Festive Garb; Status Symbols and Insignia of Offic?

300 STRUCTURES AND FURNISHINGS

301 Unclassified

302 Dwellings and Furnishings

303 Public Buildings and Furnishings; Public Areas; Status Symbols and Objects of Political Significance not worn or carried; Objects Used for Social Control

400 TRANSPORTATION

401 Unclassified

402 Water Transportation

403 Land Transportation

404 Burdens (carried by people)

500 RITUAL AND RECREATION

501 Unclassified

502 Ritual, Curing, and Cult Objects

503 Games and Gambiing Accessories of Games

504 Smoking and Narcotics

505 Musical Instruments

506 Gifts and Novelties

507 Toys 
TABLE 1 (continued)

Speciment Function Classification

(after Schneider 1970)

600 FOOD AND MEDICINES (ingredients and prepared)

601 Unclassified

602 Food and Medicines for Daily Use

603 Food and Medicines for Ritual or Festive Use

700 COMMUNICATION AND MEDIA OF EXCHANGE

701 Unclassified

702 Writing and Records

703 Sound Communication

704 Media of Exchange

Sub-Classification Suffixes

$P=$ Prehistoric

$E=$ Ethnographic

$H=$ Historic

$C=$ Contemporary

$\mathrm{N}=$ Natural 
TABLE 2

\section{Classification of Recovered Specimens \\ According to Function Category Code (see Table 1)}

101-P Chipped stone flakes

101 Springs; wire fragments; lead fragments; unidentifiable metal fragments; plastic fragments

102 Bullet

106 Glass container fragments (various colors); earthenware fragments (soft and hard paste); porcelain fragments; plastic spoon fragment; aluminum foil

107 Nails (square and round); screws; washer; nuts; bolts; glazier's points; drill bit

111 Slate tablet fragments; pencil slates; pencil leads

112 Cable fragment; clamps; chain links; paper clips; thumb tacks

201 Eyelet-headed pin

202 She11 buttons; plastic button; clothing hook; shoelace tip

203 Glass bead; necklace clasp; porcelain-headed pin; gold and silver braid fragments

301 Charcoal lumps; coal and slag lumps; asphalt lumps

302 Door hooks; tile fragments; brick fragments; concrete fragments; window glass fragments

$502 \quad$ Hypodermic needle

504 Pipe cover

$507 \quad$ GTass marbles; clay marble

601-N Gastropod shells (Rabdotus)

602 Bone scrap (mammal and bird)

703 Electrical wire; porcelain insulator fragments; light bulb fragments 
prehistoric occupation with Euro-American than to decide where "historic" ends and "contemporary" begins. Only two suffixes are therefore employed: 101-P distinguishes unclassifiable prehistoric utensils and implements from historic ones; and 601-N has been used to designate land snail shells, on the assumption that they may have served as a human food source but are certainly objects of nature. Cut-up scraps of mammal and bird bones (602), however, are unquestionably representative of human food.

Tables 3 through 6 provide data concerning Excavation Units B, C, D, and E, respectively. The tables are organized to correlate the number of specimens assigned to each appropriate functional category with the excavation level from which these specimens were recovered. The actual number of specific objects was not considered as informative as the number of specimens in a category; a glance at Table 2 will demonstrate how much more abbreviated is the list of functional categories, compared to the large and varied object inventory. It is much easier to plot activity trends and make functional interpretations at different depths and between the different units with the smaller number of variables.

For comparative purposes it was advisable to introduce some common denominator into the data, and the volume of excavated soil is employed here. Calculated in cubic meters, the actual amount of soil removed from each level of each unit is indicated on Tables 3 through 6 . In addition, the ratio of the number of specimens recovered to the volume of soil from which they were extracted was also calculated for each major functional class. The two special case categories, prehistoric flakes (101-P) and snail shells (601-N), were removed from the totals of their respective classes prior to the calculation of the class:volume ratio; these ratios are thus free of variables relating to time and natural specimens and refer only to specimens manufactured or utilized by Euro-Americans. Category:volume ratios were calculated separately for the prehistoric flakes and snail shells, permitting intra-category comparison at various depths and between the appropriate excavation units.

\section{CONCLUSIONS}

It must be stated that there were no real surprises or unusual features associated with the 1975 excavations. This is due in large part to the detailed and comprehensive report prepared by John Clark (1974), documenting the results of the 1974 Texas Historical Commission excavations at 01d Ursuline Academy. Clark found features and artifacts attributable to a prehistoric occupation of the site, underlying artifacts and disturbances associated with the historic Academy activities. The specimen inventory from the 1975 excavations exhibits both prehistoric and historic artifacts, and stratigraphically the latter overlies the former when disturbances are discounted. In fact, Clark's specimen inventory contained very few functional categories whose presence at the site were not also documented by the 1975 excavations.

The general similarities between the 1974 and 1975 stratigraphic and specimen data, or rather the absence of any significant divergences between them, permitted a clearance letter to be drafted soon after the completion of a preliminary analys is of the field data. This letter summarized the excavation 


\section{TABLE 3}

Classification of Specimens Recovered from Excavation Unit B

Functional classes and Category Codes (see Tables 1 and 2)

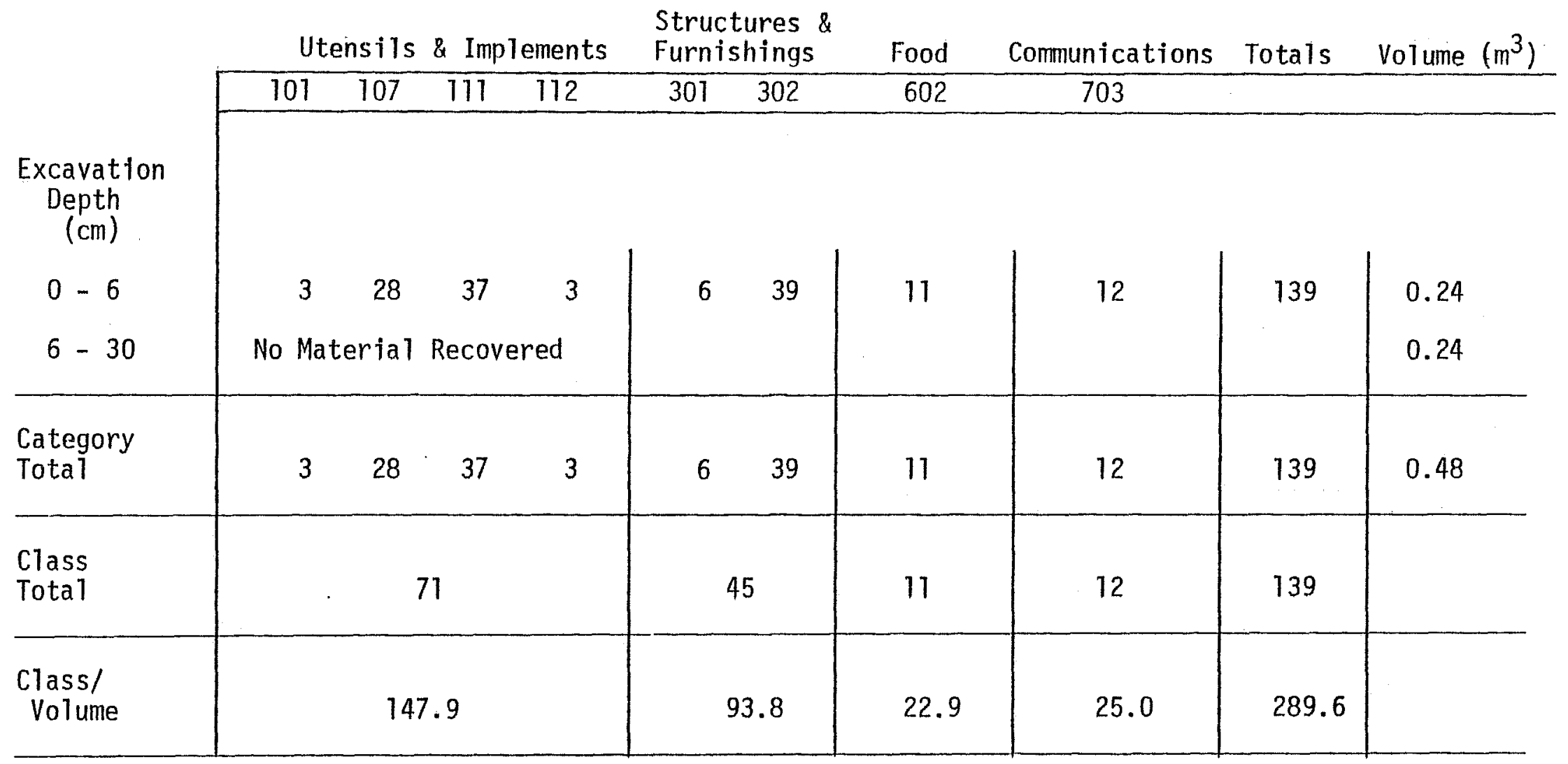


TABLE 4

Classification of Specimens Recovered from Excavation Unit $C$

Functional Classes and Category Codes (see Tables 1 and 2)

\begin{tabular}{|c|c|c|c|c|c|c|c|c|c|c|c|c|c|c|c|c|c|c|c|}
\hline $\begin{array}{l}\text { Excavation } \\
\text { Depth } \\
\text { (cm) }\end{array}$ & \multicolumn{7}{|c|}{ Utensils \& Implements } & \multicolumn{3}{|c|}{$\begin{array}{c}\text { Dress \& } \\
\text { Adornment } \\
201 \quad 202 \quad 203\end{array}$} & \multicolumn{2}{|c|}{$\begin{array}{l}\text { Structures \& } \\
\text { Furnishings } \\
301 \quad 302\end{array}$} & \multicolumn{2}{|c|}{$\begin{array}{l}\text { Ritual \& } \\
\text { Recreation } \\
502 \quad 507\end{array}$} & \multicolumn{2}{|c|}{ Food } & $\begin{array}{c}\text { Communication } \\
703\end{array}$ & Total & $\begin{array}{r}\text { Volume } \\
\left(\mathrm{m}^{3}\right)\end{array}$ \\
\hline $0-10$ & 110 & 26 & 1 & 33 & 50 & 50 & 4 & 1 & 4 & 3 & 72 & 36 & 1 & 2 & 47 & 90 & 1 & 531 & 0.40 \\
\hline $10-20$ & 25 & & & 3 & 1 & 11 & & & & & 20 & 1 & & & 4 & 4 & & 69 & 0.10 \\
\hline $20-30$ & 15 & 1 & & 2 & 1 & 2 & & . & & & 6 & 2 & & & 8 & 1 & & 38 & 0.10 \\
\hline $\begin{array}{c}\text { Category } \\
\text { Total }\end{array}$ & 150 & 27 & 1 & 38 & 52 & 63 & 4 & 1 & 4 & 3 & 98 & 39 & 1 & 2 & 59 & 95 & 1 & 638 & 0.60 \\
\hline $\begin{array}{l}\text { Class Total } \\
\text { (without } \\
101-\mathrm{P} \text { or } \\
601-\mathrm{N} \text { ) }\end{array}$ & & & & 85 & & & & & 8 & & 1 & & 3 & & & 95 & 1 & 429 & \\
\hline $\begin{array}{l}\text { Class / Volume } \\
\text { (without } \\
101-\mathrm{P} \text { or } \\
601-N \text { ) }\end{array}$ & & & & 08.3 & & & & & 3.3 & & & 8.3 & 5. & & & 158.3 & 1.7 & 715.0 & \\
\hline
\end{tabular}

$101-P /$ Vol. $\quad 250.0$

$601-\mathrm{N} / \mathrm{Vol}$. 
TABLE 5

Classification of Specimens Recovered from Excavation Unit $D$

Functional Classes and Category Codes (see Tables 1 and 2)

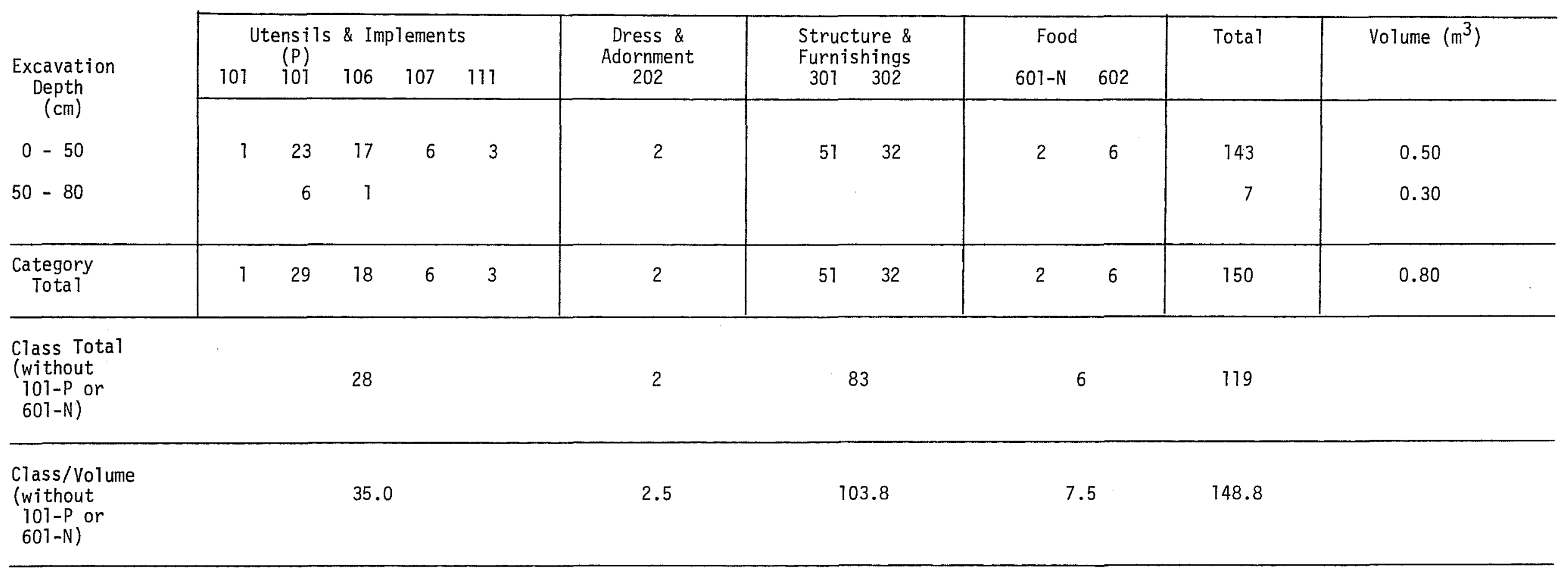

$101-P / V_{01}$

36.3

601-N/Vo1 .

2.5 


\section{TABLE 6}

Classification of Specimens Recovered from Excavation Unit $E$

Functional Classes and Category Codes (see Tables 1 and 2)

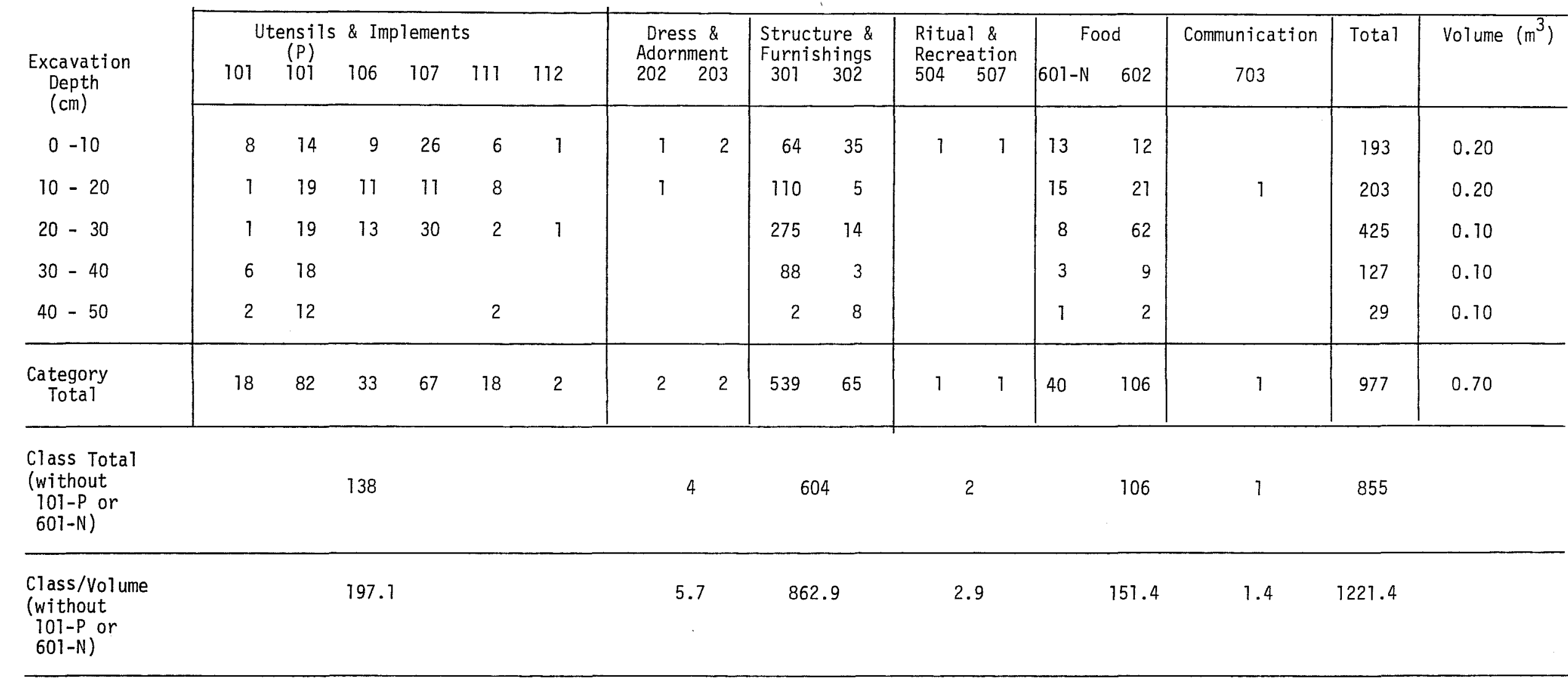

$101-\mathrm{P} / \mathrm{V} 01$

117.1

$601-\mathrm{N} / \mathrm{VoT}$. 
Figure 7. Selected Specimens Recovered from the Dormitory Excavation units. All specimens recovered between 0-10 centimeters below ground surface uniess otherwise indicated. (Function category code in parentheses.)

a, Hypodermic needle (502)

b, Hand painted earthenware (106)

c, Hand painted earthenware (106)

d, Marginally retouched chipped stone flake (101)

e, Undecorated majolica (106)

$f$, Undecorated porcelain (106)

$g$, Bone scrap (602)

$h$, Glass marble (507)

$i$, Unglazed sewer tile (302)

$j$, Pencil lead (111)

$k$, Slate (117)

l, Bullet (102)

$\mathrm{m}$, Porcelain-headed pin (203)

$n$, She11 button (202)

0 , Giass bead (203)

$p$, Square nail (107)
Provenience

Unit C

Unit $C$

Unit D

Unit D $(51 \mathrm{~cm})$

Unit $C$

Unit $C$

Unit $\mathrm{E}(10-20 \mathrm{~cm})$

Unit $C$

Unit $C$

Unit $C$

Unit $E$

Unit $C$

Unit $C$

Unit C

Unit C 

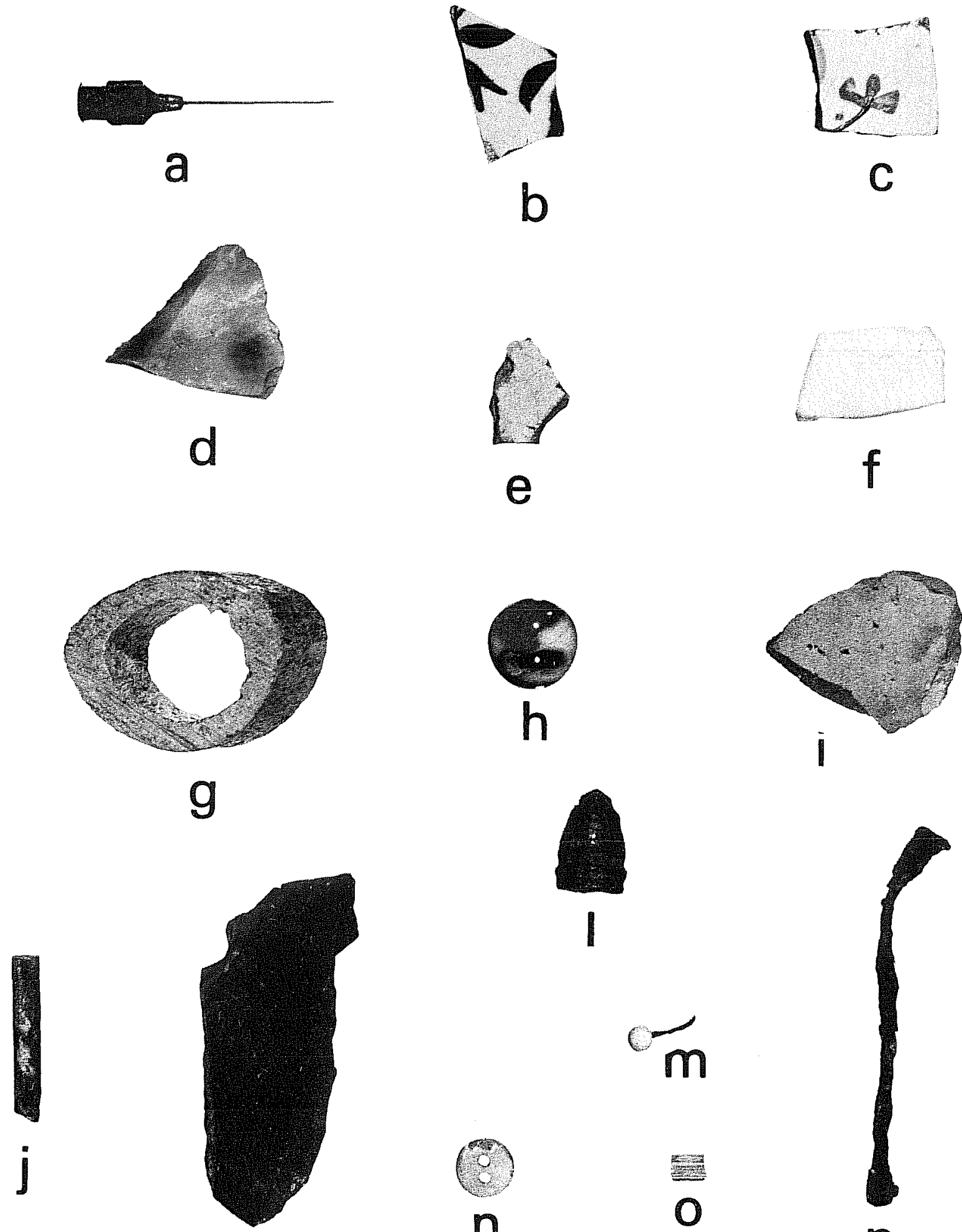
k

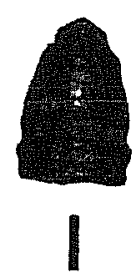

(2)

n

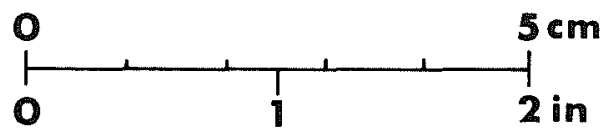


results and stated the opinion that construction activities would have no adverse effect on the cultural resources in the project area. From the scientific data obtained through excavation, it would be possible to predict to a sufficient degree the nature of stratigraphy to be altered or of artifacts to be removed or disturbed.

The fact that no unexpected or unusual data were recovered from the 1975 test excavations should by no means suggest that they were without scientific importance. On the contrary, even the limited investigations conducted more than bear out Clark's (1974:1) prediction:

It is believed that more extensive excavations can provide important data for use in the reconstruction and interpretation of the site and data concerning the social and religious history of the site and San Antonio in general.

The first observation that can be made is a confirmation of Clark's landfill gradient. Based on the profiles from his 10 test pits, it seems that the greatest amount of landfilling activity and associated debris occurred in the southernmost portion of the site (Clark 1974:8), between the San Antonio River and the south compound wall (Fig. 1). Speaking of this particular area, Clark (1974:14) states:

Since a large portion of that deposit consists of yellow paste brick and other artifacts attributable to the 1912 construction of the main school building, the deposit appears to date from that construction period.

Neither the character of the disturbed upper stratum in the dormitory courtyard, nor the depth of this disturbance, nor the associated artifacts show similarities with the southern portions of the site. Other causes and times for the disturbance and artifact deposition must be sought.

Before taking up this question, a brief digression is in order to emphasize the concentration of specimens which characterizes the dormitory courtyard portion of the site. Excluding the interior Unit B data, a comparison can be made between the three courtyard units excavated in 1975 and the 10 units excavated in other parts of the site in 1974. Table 7 provides figures for the total number of specimens recovered, the total volume of excavated soil, and a ratio of specimens per cubic meter. In sum, the dormitory courtyard excavations yielded almost 11 times the number of specimens as did the 10 1974 units, from only 3.5\% of the volume of soil. As previously mentioned, very few additional functional categories characterize the 1974 specimen inventory in comparison with that of 1975. These facts suggest that the dormitory courtyard is both a microcosm of almost every activity that took place at the site, as well as being the focus of those activities. These assumptions certainly seem valid for the historic academy occupation of the site; and the available evidence suggests that they hold for the prehistoric occupation as well.

For the above assumptions to have any validity, it must be demonstrated that the specimens were recovered from a location which varied, either horizontaliy or vertically, little or not at all from their original deposition. This is 
TABLE 7

Comparison of 1974 and 1975 Excavation Data

\begin{tabular}{|c|c|c|}
\hline & 1974 & 1975 \\
\hline Unit Data Employed & $\# 1-10$ & $C, D, E$ \\
\hline $\begin{array}{c}\text { Number of Specimens } \\
\text { Recovered }\end{array}$ & 4,667 & 1,765 \\
\hline $\begin{array}{l}\text { Volume of Soil } \\
\text { Excavated }\left(\mathrm{m}^{3}\right)\end{array}$ & 74.47 & 2.58 \\
\hline $\begin{array}{l}\text { Ratio of Specimens to } \\
\text { Volume }\left(\mathrm{H} / \mathrm{m}^{3}\right)\end{array}$ & 62.7 & 684.1 \\
\hline \multicolumn{3}{|c|}{1975 Specimens/Volume $\div 1974$ Specimens $/$ Volume $=10.9$} \\
\hline 1975 Volume $\div 1974$ Vo & $46 \%$ & \\
\hline
\end{tabular}

related directly to the nature of the disturbance noted from 0 centimeters to approximateiy 50 centimeters below the courtyard ground surface.

Several factors suggest that the subsurface disturbance was neither a recent phenomenon nor the result of landfill activity which might redeposit artifacts. Mention has already been made of the fact that the courtyard stratigraphy and specimen inventory do not reflect those associated with landfill from the 1912 classroom building construction. The fact that the courtyard in 1915 appeared much as it does today (Sr. Genevieve Babin, personal communication), including the presence of trees and bushes, further suggests that the 1912 construction activities had little effect on this portion of the site. Finally, Fox (see Appendix) states that the majority of the ceramic sherds recovered from the courtyard excavations are attributable to the last quarter of the 19th century, or the decades immediately following the construction of the dormitory in 1870 (Clark 1974:7). While some disturbance must be expected from the time of the building's construction, there are both the lack of any documented subsequent disturbance and the apparent consistency of associated historic artifacts. The tentative conclusion is that only natural subsurface movement and probably minor landscaping or gardening activities account for courtyard disturbances since the construction of the dormitory. Artifacts may have been vertically shifted and jumbled, accounting for prehistoric flakes in levels with 19th century specimens; but it is unlikely that new artifacts were redeposited from elsewhere or that very much horizontal shifting from places of original deposition took place.

A case having been made for dormitory courtyard specimens being at least horizontally in situ, it is now possible to discuss the comparative location of functional classes and categories and to make some activity interpretations. 
The preceding discussion has concerned the three exterior excavation units. in that the basement unit $B$ is a special case. Excavation of the basement into the subsoil in 1870 effectively removed all traces of any prehistoric occupation, while subsequent use of the basement rooms for food storage and kitchen ( $\mathrm{Sr}$. Genevieve Babin, personal communication; Fig. 3) undoubtedly resulted in its floor being periodically swept. The numbers of specimens in the identifiable function categories are small, as are the class totals (Table 3). It is difficult to speak of trends in the data, as it is a unique unit. The deposition of specimens representing Utensils and Implements is assumed to reflect random loss: nails, nuts, bolts, etc. (Category 107) dropped during maintenance activities and a slate (Category 117) possibly broken while a student was carrying food between the kitchen and storage areas. Food remains (Category 602) are perhaps surprisingly low in number; but then unit $B$ was located in a room which was apparently employed neither as a kitchen nor for food storage (Figs. 2,3). The relatively small number of building fragments (Category 302) seems to suggest that no renovation of the basement was ever conducted, at least in the particular room investigated. Specimens of communication (Category 703) are primarily electrical debris; while small in absolute number, they far outweigh the numbers recovered outside (Tables 4,6 ) due to the lighting system running the length of the basement ceiling. It is interesting to note that Unit $B$ had the least amount of soil removed and Unit $D$ had the most; the former, however, had almost twice the number of specimens per cubic meter, discounting prehistoric artifacts and snail shells in unit $D$ for comparability (Tables 3,5).

In comparison with the other two exterior units, Unit $D$ exhibits very little activity either prehistorically or historically; this is evidenced both by low totals in individual functional categories and by the small overall specimen per cubic meter ratio (Tables 4-6). It can be concluded from this data that in the late 19th and 20th centuries, at least, the smaller, western portion of the courtyard (Figs. 2, 5a) was less popular than the larger, eastern portion (Figs. 2, 6a).

The apparent popularity of the eastern courtyard area in which units $C$ and $E$ were located was probably attributable to several factors. In addition to simply being larger than the western portion and thus able to accommodate more people and activities, it was also more open and accessible; a large tree in the western area (Figs. 5a, 6a) served to further reduce the available space. Most significani, however, was the fact that the eastern portion was bounded by pedestrian walkways on three sides, leading to doorways at each end (Fig. 2, 6a). Pedestrians would be constantly walking by and across the area, stopping, sitting, depositing artifacts or breaking and depressing into the lawn artifacts dropped by their immediate predecessors.

Nevertheless, despite a separation of only 6.25 meters (20.6 feet) between units $C$ and $E$, their specimen inventories exhibit some interesting differences which may prove to be significant in reconstructing activities. The volumes of excavated soil are fairly comparable, differing by only one-tenth of a cubic meter; their specimens per cubic meter ratios, however, are more divergent, with Unit $E$ approaching twice as many specimens (excluding prehistoric flakes and snail shel7s, as usual) as unit C (Tables 4,6 ). 
The difference seems primarily attributable to the Structures and Furnishings function class, including both unclassified items such as coal, charcoal and slag lumps (Category 301) and building material debris (Category 302) reflecting both construction and hardware fittings (Table 2). The latter concentration suggests some renovation or repair activity conducted in the vicinity of the south dormitory door, work not documented by the research for this report. The former concentration might be interpreted as the accumulation from coalburning stoves or heaters which were periodically emptied and deposited in the courtyard east of the south dormitory door.

The intentional dumping of domestic refuse in the courtyard, as suggested above, is somewhat surprising in view of Sr. Genevieve Babin's statement that the kitchen midden was located behind the dormitory (north) in the vicinity of the northeast corner (Figs. 1,2). This might be supported architecturally by the presence of a door at this corner leading outside from the pantry/ dining room wing of the dormitory (Fig. 3) and archaeologically by the relatively low numbers of food remains (Category 602) recovered from the courtyard. Picnics, snacking or domestic animals (dogs, cats) might be expected to account for a considerable amount of bone scrap over a period of a century.

The consistently higher numbers of items assigned to the Utensils and Implements, Dress and Adornment, and Ritual and Recreation function classes recovered from unit $E$ in comparison with unit $C$ (Tables 4,6 ) can on $7 y$ be interpreted as suggesting the western half of this portion of the courtyard was more heavily utilized than was the eastern half. Verification comes from the fact that unit $E$ was located close to the main north-south walkway (Fig. 2, 6a) which connected the central doors of the two primary buildings and served as the most direct route between the dormitory and main courtyard to the south.

One final point might be made concerning the prehistoric occupation debris recovered from the courtyard. Calculations of specimens per cubic meter ratios were done separately from the historic artifacts, for both chipped stone flakes (Category 101-P) and 1and snajl shells (Category 601-N); the latter seem to be consistently associated with prehistoric occupation areas and artifacts (Clark 1974:33). These ratios are provided at the bottom of Tables 4,5 and 6 , reflecting Units $C, D$ and $E$ respectively. Spatially, Unit $D$ is the farthest west, with unit $E$ in the center and unit $C$ the easternmost excavation. A trend may be noted toward more prehistoric material as one proceeds farther east, both in the absolute numbers of specimens and in the ratio of specimens per cubic meter. The fact that unit $D$ had a greater volume of soil removed than did the other two units, and still reflected the smallest prehistoric inventory, simply amplifies this proposed trend. The excavation units form an east-west line which roughly parallels the San Antonio River channel at the site (Figs. $1,2)$, and continuation of this line farther east leads one beyond the east end of the dormitory and into a contemporary parking lot. Continuation of the trend toward increasing evidence of prehistoric occupation also leads one toward the east and under this parking lot.

Clark (1974:37) concluded his report with the following statement:

It can be seen that the excavations and historical research herein described represent only a preliminary test of available 
resources of Ursul ine Academy. Hypotheses have been proposed so that more problem-oriented investigations can be conducted at some future data. In addition to the resources here in described, the basement of the 1912 structure may be intact, filled with rubble. It is capped by asphait now and will apparentiy not be seriously disturbed for some time.

In concluding the present report, it might be stated that "problem-oriented investigations" are still awaited at 01d Ursuline Academy; this goal may have been furthered by the 1975 investigations but has certainiy not been reached. Should the time ever come when the asphalt capping is removed, permitting additional research in the basement of the 1972 building, efforts should be made to investigate the postulated prehistoric occupation which is thought to also lie protected at the present time.

\section{REFERENCES CITED}

Clark, John W., Jr.

1974 Archeological Excavations at Ursul ine Academy, San Antonio, Texas: June, 1974. Office of the State Archeologist, Texas Historical Commission. Austin.

Schneider, Mary Jane

1970 A Guide to Inventorying Ethnological Collections. Museum of Anthropology, University of Missouri-Columbia. Columbia. 


\section{ACKNOWLEDGMENTS}

The archaeological investigations which I conducted on the grounds of the Southwest Craft Center, formerly 01d Ursul ine Academy, were the first such activities I undertook after arriving in San Antonio the previous August. While the time allotted for actual excavation was adequate, none could be wasted due to the construction schedule and overall renovation deadlines. Budgetary considerations preciuded any paid crew members; and being new to the area, I had some misgivings about requesting volunteer assistance. I need not have worried, for South Texas is indeed blessed with a local archaeological society and several academic institutions whose associates were, and are, enthusiastic, generous of their time, and well-grounded in more than just the rudiments of field archaeology. My gratitude for the cooperation I received, both in quantity and quality, necessitates the mention by name of all whose assistance made this project possible.

Southern Texas Archaeological Association members

Nancy Clayton

BiTl Henderson

JoAnne Henderson

Sam Montgomery

Art O'Conne 11

Brian $0^{\prime}$ Conne 71
Rick Sowa

Shirley Van der Veer

W.R. Van der Veer

Ann Van Vooren

Kate Vaught

University of Texas at San Antonio students

Tom Diaz

Libby Golden

Carol Graves

Randa 71 Hilburn

Incarnate Word College

June Secrist, student
Royce Mahula

Ji 11 McDouga 17

Kay Simpson

Dena Stoner

San Antonio College

Max Witkind, faculty

I would like to extend my appreciation to all the associates of the Southuest craft Center who gave me their time and advice and who accommodated themselves to the disturbances caused by the investigations and interviews: Margaret Saunders, Chairman of the Board; Marcia Larsen; Martha Lackey; Zeke Lucasik; Harvey Kohnitz, whose field photographs appear in this report; and Dan Jenkins, whose face Tivened up the excavations. 
I would also like to thank the following people: Sr. Genevieve Babin, for an extremely pleasant and informative interview; Roland Baylor, for his consideration during the construction phase of the project; John Clark and Dan Scurlock of the Texas Historical Commission, for their advice and assistance during the entire project; Lynn Highley and Anne Fox, for valuable assistance in artifact analysis; staff members of The University of Texas at San Antonio Office of Instructional Services, for report preparation assistance; Kathy McCauley, for administrative assistance; Jeanette Burch, for manuscript typing; Elizabeth Branch for editing the manuscript; Dr. Thomas Hester, for his constant encouragement during a 11 phases of the project; and Susanna Katz, for everything. 


\title{
APPENDIX
}

Ceramic Analys is

\author{
Anne A. Fox
}




\section{DESCRIPTIONS}

Brick and Tile

Brick or Tile (6 fragments)

These are small pieces with red-brown paste and white inclusions, not large enough to determine whether they are from brick or tile.

Unglazed Sewer Tile (1 sherd)

This fragment has a granular pink paste with large red and cream inclusions, and is covered on the outside with what appears to be a thin, green slip.

Glazed Sewer Tile (1 sherd)

The granular gray paste with brown and tan inclusions has a thick lead glaze on the outside. Sewer tile has been manufactured and soid in the local area since the late 19th century (Hensley 1976; Morrison and Fourmy 1885-86).

\section{Soft Paste Earthenware}

Unglazed Flower Pot ( 5 sherds)

The low-fired, orange-tan body with smooth unglazed surfaces identifies this type of vessel. Unfortunately, there have been so few changes in the technique of making flower pots through time that it is nearly impossible to date them with any accuracy (NoeT Hume 1970:223).

Unglazed Fragment (1 sherd)

This buff-colored fragment appears to be part of a semi-circular ring which was shaped on a wheel or extruded in such a way as to be uniform and striated.

Lead Glazed (1 sherd)

Apparently from a bowl with a pinched design around the rim, the homogenous orange paste with dark inclusions and the clear lead glaze identify the vessel as being of Mexican origin. Such bowls have been popular in San Antonio throughout the 18th, 19th and early 20th centuries, and similar types are still available in the markets today. (See Fox 1974:55.)

Lead Glazed (1 sherd)

This is from a bow with in-curving rim. The paste is sandy, homogenous, tan in color with white and black inclusions. For dating, see above.

Lead Glazed (1 sherd)

Possibly from a bowl, the paste of this sherd is fine, homogenous, tan in color with occasional orange inclusions. It is glazed on the inside only. For dating see above. 
Undecorated Majolica (1 sherd)

Covered on both sides with an opaque, creamy white glaze, this is a fragment of a plate with a light, yellow-tan paste. It could have been part of any one of the plain or decorated types of this ware which was imported from Mexico throughout the 18th to early 20th centuries, and is stili made in limited quantities today (Goggin 1968:201-202).

undecorated Majulica (1 sherd)

This sherd is the same as above, but with a pink paste.

Hard Paste Earthenware

Undecorated white (7 sherds)

From various vessels, these sherds could represent plain vessels or undecorated portions of other types made in England and the United States in the 19th to early 20th centuries.

Molded Rim (1 sherd)

This is a fragment of a plate with molded or repousse design around the rim. These plates became popular in the late 19th century in this area, and similar types are still made in the United States today (Durrenburger 1965:18).

Hand Painted ( 1 sherd)

This sherd is from a cup with globular body and slightly constricted rim. Thin brown vertical lines are irregularly spaced, possibly part of a floral design. The type was probably made in the United States in the early 20th century, as it is not typical of earlier American and British wares.

Hand Painted (1 sherd)

The sherd represents a bowl painted underglaze with a floral design in blue, black and green. Similar vessels are common on sites in south Texas occupied in the middle 19th century (Schuetz 1969:Plate 12; Fox 1970:26-28).

Hand Painted ( 4 sherds)

These sherds are painted in blue floral designs under a clear glaze and represent a plate and another, unidentifiable vessel. Similar sherds have been found at other south Texas sites in middle to late 19 th century contexts (Schuetz 1969:Plate 12; Greer 1967:30).

Annular ware (1 sherd)

A bright blue on one side and white on the other, this sherd is part of a banded cup or bowl of a type first made in England in the early 19th century and popular in south Texas throughout that century (Noel Hume 1970:131; Fox 1970:31-32; Greer 1967:33-34). 
Transfer

This unidentified vessel is decorated with a purple transfer design. This type of ware was also popular in south Texas in the middle to late 19th century.

Porcelain

Undecorated ( 3 sherds)

These are fragments of a plate and an unidentifiable vessel, and could have been made in Europe or the United States, probably in the late 19th century.

Molded ( 4 sherds)

Fragments of dol1s' heads or sma 11 vessels, too sma 11 to identify. If do $11 \mathrm{~s}$, they would date to the late 19th century (Noel Hume 1970:317).

Molded (2 sherds)

These are parts of two different types of electrical insulator found throughout the area in the late 19th century (Roberson 1974:26 and 94; Durrenburger 1965: 20; Greer 1967: Figure 17). A chronology has not yet been estab7ished for such articles in south Texas, but the first electric company in San Antonio was started in 1884 (Reil1y 1885:66).

\section{OBSERVATIONS}

The small number and average size of the sherds recovered make identification tenuous in some instances. Nevertheless, the following observations can be made with some assurance, based on the author's observations at other San Antonio historic sites and published references.

The majority of the ceramic articles represented by sherds recovered in the excavations would have been present in the San Antonio area during the last quarter of the 19th century and could well have been in use at Ursuline at that time. While the imported Mexican and English wares could have been here earlier, their presence in conjunction with later types, primarily in the uppermost ten centimeters of squares $C$ and $E$, suggests the later date as their time of deposition. The colorful and poputar English vessels in particular were probably in use for several generations in San Antonio households.

\section{REFERENCES CITED}

Durrenberger, E. P.

1965 Anderson's Mi11 (41 TV 130): A Historic Site in Travis County, Texas. Texas Archeological Saciety. Bulletin 36:1-69. Austin.

Fox, Anne A.

Lead Glazed Wares. In Mission Rosario: Archeological Investigations, 1973, by KathTeen Gilmore. Texas Parks and Wildlife Department, Historic Sites and Restoration Branch, Archeological Report 14, Part I:55-60. Austin. 
Fox, Daniel E.

1970 Archeological Salvage at Mission San José, December 1969, ApriT and August 1970. Manuscript, Texas Historical Survey Committee. Austin.

Goggin, John M.

1968 Spanish Majolica in the New World. Yale University, Publications in Anthropology 72. New Haven.

Greer, John W.

1967 A Description of the Stratigraphy, Features and Artifacts from an Archeological Excavation at the Alamo. State Building Commission, Archeological Program, Repart 3. Austin.

Hensley, Frank

1976 Conversation Concerning the History of the W. S. Dickey Clay Pipe Company, Saspamco, Texas.

Morrison and Fourmy

1885-86 General Directory of the City of San Antonio. San Antonio. Noel Hume, Ivor

1970 A Guide to Artifacts of Colonial America. Knopf, New York. Reilly, J. S.

1885 San Antonio, Past, Present, and Future. San Antonio. Roberson, Wayne R.

1974 The Carrington-Covert House, Archeological Investigations of a 19th Century Residence in Austin, Texas. Office of the State Archeologist, Texas Historical Commission, Report 25 . Austin.

Schuetz, Mardith K.

1969 The History and Archeology of Mission San Juan Capistrano, Volume 2: Description of the Artifacts and Ethnohistory of the Coalhuitecan Indians. State Building Commission, Archeological Program, Report 11 (Office of the State Archeologist, Report 11). Austin. 